\title{
Work Life Balance in the Non-HR Employee Perception the Case of FMCG Companies in Sri Lanka
}

\author{
Wadanambilage Dona Naduni Madhavika \\ Faculty of Business, Sri Lanka Institute of Information Technology \\ New Kandy Road, Malabe, Sri Lanka \\ E-mail: naduni.m@sliit.lk
}

Received: Jan. 14, 2019 Accepted: Feb. 11, 2019 Online published: Feb. 17, 2019

doi:10.5296/ijhrs.v9i1.14227ＵRL: https://doi.org/10.5296/ijhrs.v9i1.14227

\begin{abstract}
The study focused on investigating the perception that the non HR employees have regarding the work life balance in their respective organizations in Fast Moving Consumer Goods (FMCG) sector in Sri Lanka. In this study; the data is collected from 16 FMCG companies in Sri Lanka which included 4 foreign (Global) companies and 12 local (Sri Lankan based) companies during the period of 6 months (June 2018 - December 2018). The study adopted the survey strategy with a sample size of 1000 . Both the online and manual methods were used in order to collect the data. According to the results obtained it was demonstrated that the perception that the non HR employees have regarding the Work Life Balance in their respective organization to be satisfactory with an average value of 4.5472 . However; it was found that there is a gap in between the perception that non HR employees in the local FMCG (Sri Lankan based FMCG companies) companies possess and the perception that non HR employees in the foreign FMCG companies (Global FMCG companies) possess regarding the work life balance in their respective organizations based on the differences in mean values.
\end{abstract}

Keywords: local and foreign FMCG, work life balance

\section{Introduction}

Work-life balance has become an everyday discourse in today's business context (Greenhaus, Collins , \& Shaw, 2003). However; it's been reported that research consisted on the work-life arena is very limited (Greenhaus \& Allen, 2011). Based on the past literature Work-Life Balance can be defined as an individual's perception of how well his or her life roles are balanced (Frone, 2003; Greenhaus \& Allen, 2011; Haar, 2013). It is the ability that an individual possess in order to maintain the balance between the work life and the personal 
life.

In Sri Lanka, it is reported that for 8 people one person suffer from mental illness (World Health Organization, 2017). One reason which causes this mental distress may be the inability of the individuals to maintain the balance between personal and work life.

The study focuses on the FMCG industry since $20 \%$ of overall employment in Sri Lanka belongs to the FMCG sector (NDB Securities, 2017). Thus; it represents large portion of the citizens in the country and also since; in the Sri Lankan context a very limited number of studies had been undertaken in this arena focusing other business sectors; the study focuses on the current status of the perception that non HR employees have regarding the "work life balance" in their respective organizations in the FMCG sector.

The FMCG sector in Sri Lanka consists of companies of two categories. These two categories include Foreign based FMCG companies (Global FMCG companies) and local FMCG companies (Sri Lankan based FMCG companies).

\section{Literature Review}

The concept of work life balance has been evolving from its origin of trade development since the eighteenth century (Chartered Institute of Personnel and Development, 2007). Since the business environment is highly dynamic in terms of economic social and legislative conditions in different countries, currently there is no universal definition on work life balance.

However; when reviewing the past literature Work-Life Balance was found to be defined as an individual's perception of how well his or her life roles are balanced (Frone, 2003; Greenhaus \& Allen, 2011; Haar, 2013).

With the entry of women into workforce the concept of "work life balance" has been triggered. Since the dual income parents were encountering in maintaining the balance between family and work responsibilities most of the firms started in featuring "family friendly" practices in their respective organizations such as child care facility. In addition to that other good practices related to work life balance includes the paid maternity leaves which allowed the opportunity for working women to work more flexibly (Pocock, 2005).

There are a number of studies that has tried to find whether work life balance positively affects the employees' performances. One such study is a study undertaken by Bloom and Van Reenen (2007); which was conducted to identify whether" management practices of "Anglo-Saxon" and higher level of market competition causes work productivity at the expense of work life balance of the employees. The study was undertaken with 732 medium sized manufacturing companies located in France, Germany, UK and US. The results of this study had revealed that the best management practices has a correlation with the work life balance of the organization which allows the organizations in order to be more productive.

Certain studies highlight and evaluate that work life balance policies has to be implemented in workplace because of ethical issues and concerns (Frame \& Hartog, 2003). 
Although in the Sri Lankan context; studies related to work life balance in the FMCG sector is limited; a considerable number of studies had been undertaken regarding the work life balance focusing employees of other business sectors.

One such study is a the study conducted in order to analyze the impact of work life balance on job satisfaction of employees in the Sri Lankan private sector commercial banks (Adikaram, 2016). According to the study using correlation and regression tests; it has been found that; work life balance has a significant impact on the job satisfaction of employees in the Sri Lankan private sector commercial banks.

Another study undertaken regarding the work life balance and employee performance with a sample size of 96 employees working in seven apparel firms in Sri Lanka it was found that there is a positive relationship between work life balance and employee performance (Dissanayaka \& Ali, 2013). The study had involved 96 employees working in seven apparel firms in Sri Lanka. Thus; the study had suggested that improvements of Work life balance practices in the organizations could bring better employee performances.

\section{Objectives of the Study}

1. What is the perception that non HR employees in FMCG companies have regarding the work life balance in their respective organizations?

2. Is there a gap between the perception of work life balance in between the non HR employees in Foreign FMCG companies (Global FMCG companies) and local FMCG companies (Sri Lankan Based FMCG companies)?

\section{Significance of the Study}

Currently in the Sri Lankan context although studies had been undertaken with regards to work life balance in other industries; there were no studies to be found focusing the work life balance in the FMCG sector. However; FMCG sector in Sri Lanka represents $20 \%$ of the Sri Lankan employment (NDB Securities, 2017). Thus; it is significant for the Sri Lankan work force to know the current status of work life balance practices available in the FMCG companies in the country. Therefore; the present study has focused to find the perception of non HR employees about work life balance in the FMCG sector in Sri Lanka while trying to address the empirical gap which exists with this regards in the Sri Lankan context.

In addition; Sri Lanka FMCG industry is considered to be one of the fastest growing sector in the Sri Lankan economy which contributes to more than 30\% of the Sri Lankan GDP (NDB Securities, 2017). The Sri Lankan FMCG industry consists of both the large foreign FMCG companies (Nestle, Fonterra, Unilever, Coca-Cola and etc.) and local FMCG companies (CBL, Maliban, NMK Pvt Ltd, Dilmah, Hemas and etc.) with well-established supply chain structure and brand names which makes the competition within the companies in the Sri Lankan FMCG industry intense.

Therefore; in order to achieve competitive advantage the FMCG companies try to attract highly skilled and semi-skilled workers and retaining the skilled employees within the company. Thus; in order retain highly skilled employees, the companies should know the 
perception that the current employees working in the respective organizations have regarding the HR practices in their organizations. Most importantly, since; the employees tend to stay in those organizations in which they can maintain a balance between the work life and the personal life; the present study focuses on exploring the perception that the employees have regarding the HR practices related to work life balance in the respective organizations.

In addition; the study also contributes the management in the respective companies to take insights in order design better HR practices to maintain the work life balance of the employees which will positively contributes in having a more mentally healthy work force in the country.

\section{Methodology}

The study had adopted abductive approach and as the primary data collection strategy; survey strategy is adopted in the study, since high level of general capability is associated with the strategy with a representation of a large population. A self-administered questionnaire was used in order to obtain the perception that the non HR employees have regarding the HR practices in their respective organizations. In order to measure the perception the employees have regarding the work life balance 11 statements were used and the respondent was given a likert scale of 7 asking to range from "Strongly Disagree" to "Strongly Agree". Based on the mean values received for likert scale values; the satisfactory level of employees with regards to each dimension which measured the availability of HR practices related to Work Life Balance in local and foreign FMCG companies was decided.

Table 1. Statements used to measure the perception that employees have about Work Life Balance

\begin{tabular}{l|l}
\hline Code & Question \\
\hline WB01 & My organization allows employees to use flexible working hours on our job roles \\
\hline WB02 & The management always assigns reasonable and achievable work and tasks. \\
\hline WB03 & $\begin{array}{l}\text { My management does not expect employees to attend office matters when the } \\
\text { employees are on leave }\end{array}$ \\
\hline WB04 & My Organization strongly considers personal goals and values. \\
\hline WB05 & My HR Division encourages to enjoy work-life balance. \\
\hline WB06 & My organization allows employees to enjoy full leave entitlement. \\
\hline WB07 & $\begin{array}{l}\text { My organization considers personal matters and work life balance when effecting } \\
\text { transfers for employees. }\end{array}$ \\
\hline WB08 & $\begin{array}{l}\text { My organization owns holiday homes/bungalows which can be used freely for } \\
\text { employees to spend their holiday with family. }\end{array}$ \\
\hline WB09 & \begin{tabular}{l} 
The employees are provided with GYM facilities etc. \\
\hline WB10
\end{tabular} My organization has a sound medical scheme for the entire family. \\
\hline WB11 & My organization provides "Lifelong" employment for "Performers". \\
\hline
\end{tabular}




\section{Macrothink}

International Journal of Human Resource Studies

ISSN 2162-3058 2019, Vol. 9, No. 1

The target study population was the non HR executive and above level employees in the FMCG companies. The non-probability convenience sampling was used in order to select the sample and the companies were chosen only from the Western province due to time and other practical reasons. The sample consisted of all together 1000 responses which consisted 576 responses from the local FMCG companies and 424 responses from the foreign FMCG companies.

The entire sample of 1000 was tested for reliability and validity in which the obtained Reliability Cronbach's Alpha was 0.940 and Validity KMO was 0.903.

The data collected through questionnaires was analyzed using the SPSS software and descriptive techniques were used in order to obtain the results.

\section{Limitations}

The entire sample of 1000 consisted only of the non HR employees working in the FMCG companies based in the Western Province (Kalutara, Colombo and Gampaha Districts). In addition; the sample focused only on the executive and above level employees since then the respondents are assumed to have quite the same level of educational background.

\section{Analysis and Interpretation}

\subsection{Demographic Variables}

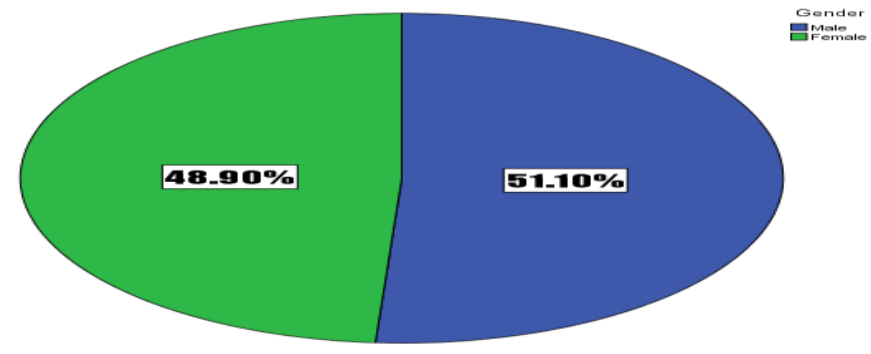

Figure 1. Gender

$48.9 \%$ of the entire sample consisted of females while majority of the sample consisted on males which was $51.10 \%$ of the sample.

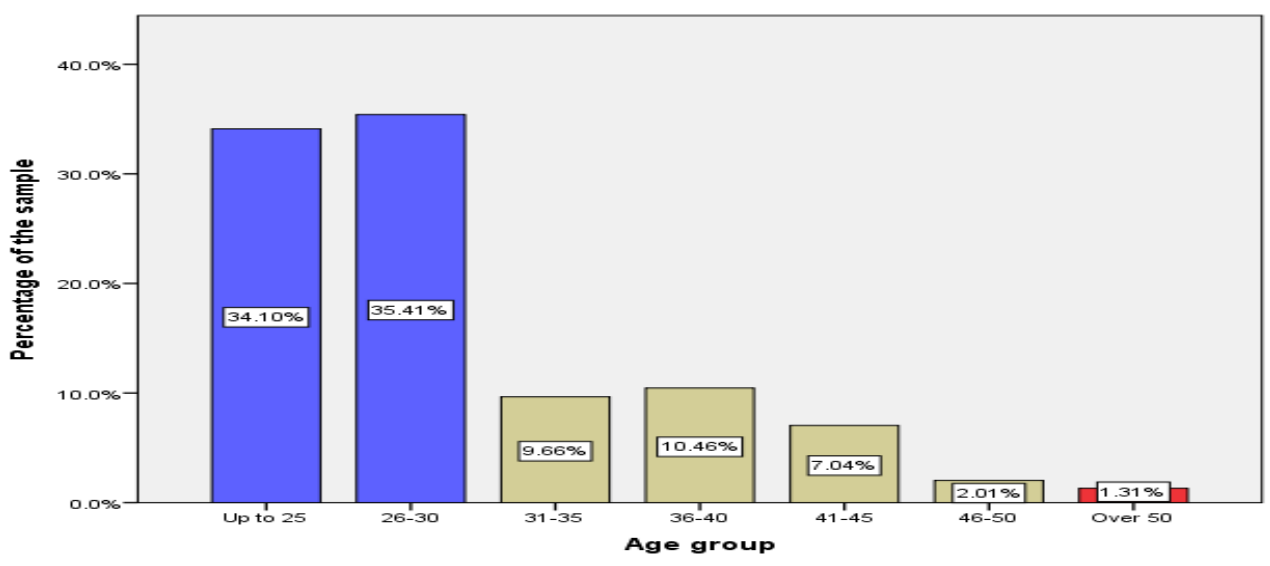

Figure 1. Age group 


\section{Macrothink}

International Journal of Human Resource Studies

ISSN 2162-3058 2019, Vol. 9, No. 1

Based on Figure 2 it's evident that in the sample majority of the individuals were in the age limit in between 26-30 Age group which represented a majority of $35.41 \%$ of the sample. Minimum percentage of employees belonged to the age limit "over 50" which represented only $1.31 \%$ of the sample considered.

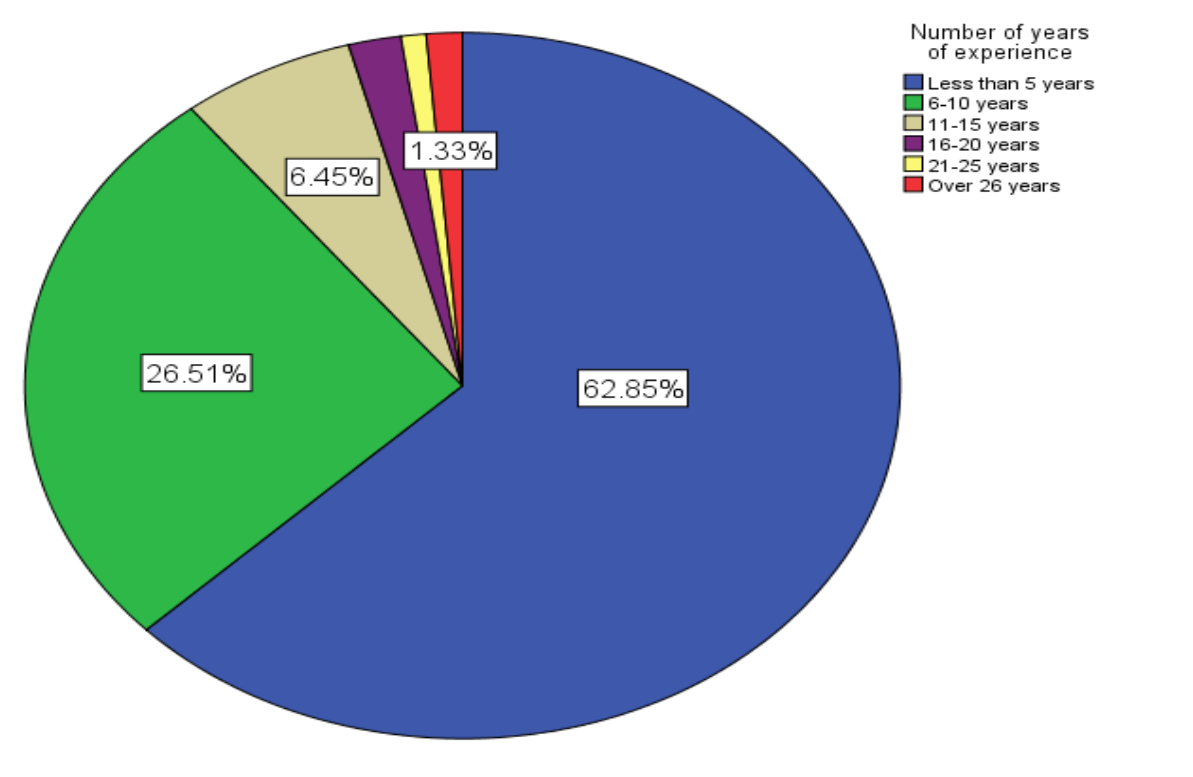

Figure 3. Number of Years of Experience

In the sample majority of $62.85 \%$ of the sample represented the employees who has had an experience which was less than 5 years. Thus; the findings of the study might be biased according to the perception that the employees have had within a relatively short period of time. Only $1.33 \%$ of the sample represented the employees who had worked in the respective companies for over 26 years.

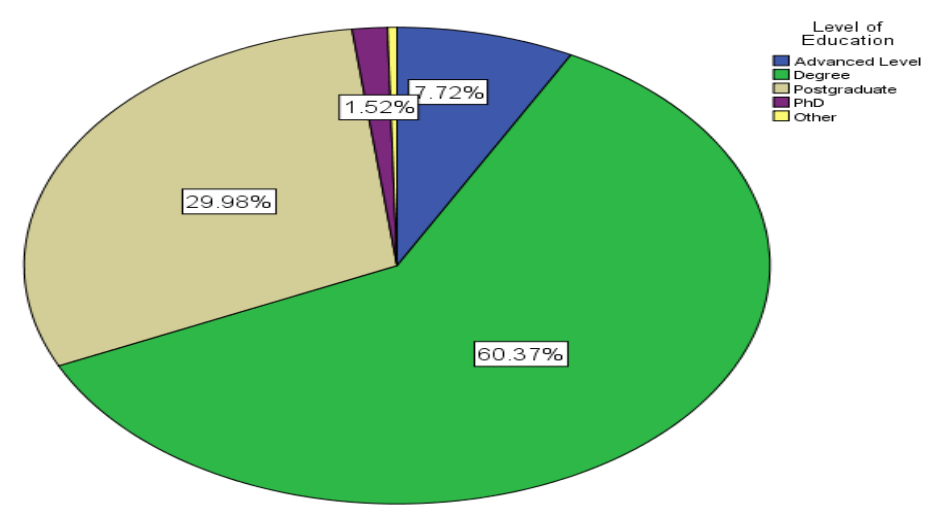

Figure 4. Level of Education

Based on Figure 4 in the sample most of the individuals' highest level of education has been Degree qualification which represented $60.37 \%$ of the sample. 
Table 2. Category of FMCG Company in the Sample

\begin{tabular}{|c|c|c|c|c|c|}
\hline & Frequency & Percent & \begin{tabular}{|l} 
Valid \\
Percent
\end{tabular} & $\begin{array}{l}\text { Cumulative } \\
\text { Percent }\end{array}$ \\
\hline \multirow[t]{3}{*}{ Valid } & Local & 576 & 57.6 & 57.6 & 57.6 \\
\hline & Foreign & 424 & 42.4 & 42.4 & 100.0 \\
\hline & Total & 1000 & 100.0 & 100.0 & \\
\hline
\end{tabular}

The entire sample of 1000 FMCG companies considered consisted of 576 local FMCG companies representing $57.6 \%$ of the local FMCG companies in the entire sample while 424 Foreign FMCG companies representing $42.40 \%$ of the entire sample.

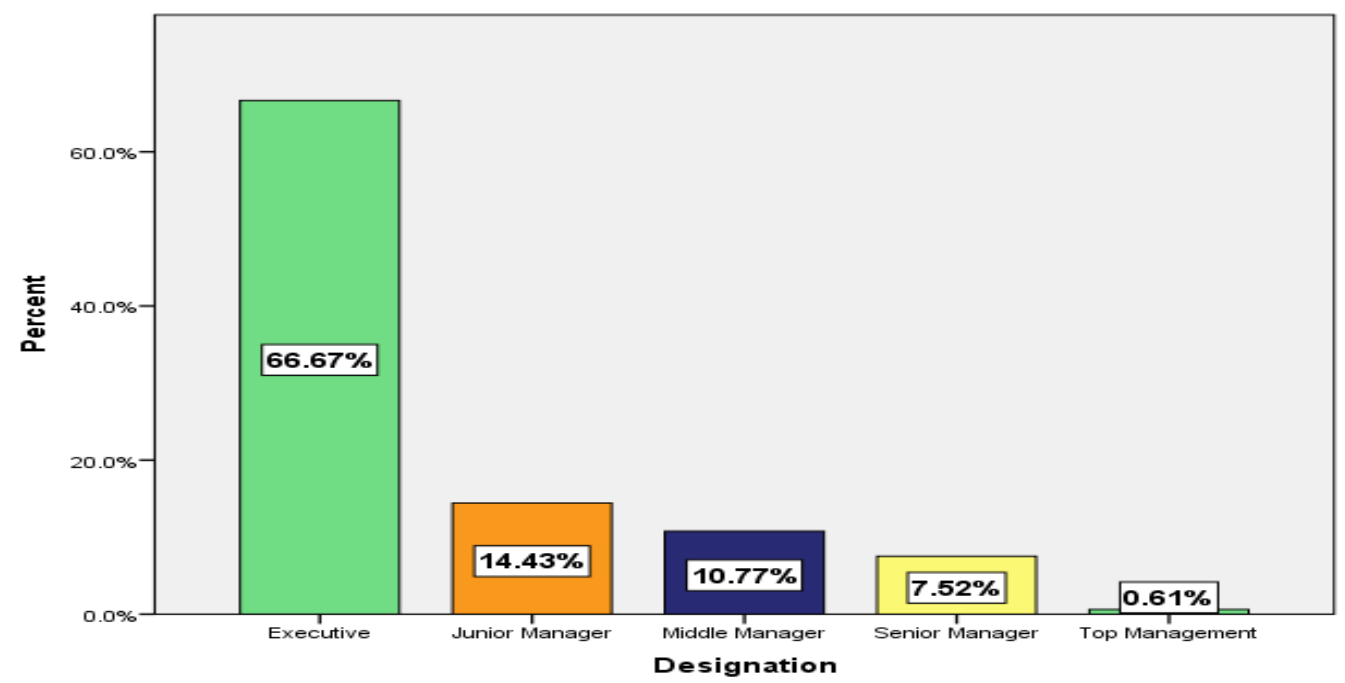

Figure 5. Designation Composition in the Sample

Majority of the sample was from the executive category which represented $66.67 \%$ of the sample. Only $0.61 \%$ of the sample represented the top management category level employees in the sample. Thus; the results of the survey represents more of the perception of the executive category employees regarding the human resources management practices in their respective organizations.

Table 3. Descriptive for Work life Balance Dimension

\begin{tabular}{l|l|l|l|l|l|l}
\hline & $\mathrm{N}$ & Range & Minimum & Maximum & Mean & Std. Deviation \\
\hline WB01 & 913 & 5 & 1 & 6 & 4.50 & 1.579 \\
\hline WB02 & 912 & 5 & 1 & 6 & 4.67 & 1.170 \\
\hline WB03 & 912 & 5 & 1 & 6 & $\underline{\mathbf{4 . 1 5}}$ & 1.729 \\
\hline WB04 & 912 & 5 & 1 & 6 & 4.77 & 1.136 \\
\hline WB05 & 912 & 5 & 1 & 6 & 4.74 & 1.265 \\
\hline WB06 & 897 & 5 & 1 & 6 & 4.79 & 1.212 \\
\hline WB07 & 909 & 5 & 1 & 6 & 4.52 & 1.221 \\
\hline WB08 & 909 & 5 & 1 & 6 & 3.86 & 1.874 \\
\hline WB09 & 908 & 5 & 1 & 6 & 4.20 & 1.747 \\
\hline WB10 & 910 & 5 & 1 & 6 & $\mathbf{4 . 9 0}$ & 1.173 \\
\hline WB11 & 910 & 5 & 1 & 6 & 4.72 & 1.379 \\
\hline AWB & 894 & 5.00 & 1.00 & 6.00 & 4.5472 & 1.12900 \\
\hline Valid N (listwise) & 894 & & & & & \\
\hline
\end{tabular}


For Work life Balance dimension, descriptive statistics were taken for all 11 measures and AWB represents the Average Work Life Balance dimension received by the selected 16 companies in the FMCG sector. As observed the mean value received for AWB is 4.5472 which seems to be in a satisfactory level. When the 11 measures are concerned the minimum mean value of 4.15 is received by WB03 where the statement measured whether "My management does not expect employees to attend office matters when the employees are on leave". The maximum mean value of 4.90 is received for WB10 where the statement was whether "My organization has a sound medical scheme for the entire family".

Table 4. Comparison of Mean Values received for Work Life Balance aspect by Local and Foreign FMCG Companies

\begin{tabular}{|c|c|c|c|c|c|}
\hline & Category & $\mathrm{N}$ & Mean & $\begin{array}{l}\text { Mean } \\
\text { difference } \\
\text { (Foreign } \\
\text { Local) }\end{array}$ & $\begin{array}{l}\text { Std. } \\
\text { Deviation }\end{array}$ \\
\hline \multirow[t]{2}{*}{ WB01 } & Local & 533 & 4.09 & 0.98 & 1.636 \\
\hline & Foreign & 380 & 5.07 & & 1.294 \\
\hline \multirow[t]{2}{*}{ WB02 } & Local & 533 & 4.41 & 0.59 & 1.074 \\
\hline & Foreign & 379 & 5.02 & & 1.208 \\
\hline \multirow[t]{2}{*}{ WB03 } & Local & 533 & 3.42 & 1.75 & 1.651 \\
\hline & Foreign & 379 & 5.17 & & 1.253 \\
\hline \multirow[t]{2}{*}{ WB04 } & Local & 533 & 4.56 & 0.51 & 1.009 \\
\hline & \begin{tabular}{|l|} 
Foreign \\
\end{tabular} & 379 & 5.07 & & 1.232 \\
\hline \multirow[t]{2}{*}{ WB05 } & Local & 533 & 4.40 & 0.82 & 1.198 \\
\hline & Foreign & 379 & 5.22 & & 1.200 \\
\hline \multirow[t]{2}{*}{ WB06 } & Local & 519 & 4.46 & 0.74 & 1.070 \\
\hline & Foreign & 378 & 5.24 & & 1.252 \\
\hline \multirow[t]{2}{*}{ WB07 } & Local & 531 & 4.14 & 0.91 & 1.120 \\
\hline & Foreign & 378 & 5.05 & & 1.159 \\
\hline \multirow[t]{2}{*}{ WB08 } & Local & 530 & 3.13 & 1.77 & 1.855 \\
\hline & Foreign & 379 & 4.90 & & 1.336 \\
\hline \multirow[t]{2}{*}{ WB09 } & Local & 529 & 3.68 & 1.25 & 1.899 \\
\hline & Foreign & 379 & 4.93 & & 1.173 \\
\hline \multirow[t]{2}{*}{ WB10 } & Local & 531 & 4.80 & 0.25 & 1.081 \\
\hline & Foreign & 379 & 5.05 & & 1.278 \\
\hline \multirow{2}{*}{ WB11 } & Local & 531 & 4.58 & 0.33 & 1.418 \\
\hline & Foreign & 379 & 4.91 & & 1.301 \\
\hline
\end{tabular}

According to the Table 4.22 for all the statements which measured the Work Life Balance Dimension the mean value for local FMCG companies has been relatively less than that of foreign FMCG category of companies. The highest mean difference of 1.77 was received by WB08 which measured whether "the organization owns holiday homes/bungalows which can be used freely for employees to spend their holiday with family".

\section{Discussion}

$48.90 \%$ of the entire study sample consisted of females while $51.10 \%$ represented males. The sample consisted of majority of $35.41 \%$ of the individuals in the age limit between 26-30 Age Group.Based on the mean value of 4.55 recorded for all the dimensions which measured the availability of Work Life Balance aspect it is concluded that the non HR employees in the 
overall FMCG sector seems to be in a satisfactory level.

However; the minimum mean value of 4.15 is received by WB03 where the statement measured whether "My management does not expect employees to attend office matters when the employees are on leave". However; this might affect the mental health of the employees since they lack time for relaxation and spend time with their loved ones at home which also must have been a major reason for 8 people in Sri Lanka suffer from mental illness (World health Organization, 2017). This scenario just not only affect the mental health of the employees but also a plethora of studies suggests that the depression causes the reduction of productivity, increasing health care cost and staff turnover of the organizations in the long run.

In addition to the above based on the comparison made in between mean values of local and foreign FMCG companies (Table 4) it was concluded that the HR practices related to work life balance aspect in foreign FMCG companies has been better than that of local FMCG companies in terms of all the dimensions.

\section{Conclusion}

Based on the survey findings with regards to the Work Life Balance dimension - despite of the category of the FMCG Company it was found that employees are expected to attend office matter even when they are on leave". However; this might affect the mental health of the employees since they lack time for relaxation and spend time with their loved ones at home which also must have been a major reason for 8 people in Sri Lanka suffer from mental illness (World health Organization, 2017). This scenario just not only affect the mental health of the employees but also a number of studies had suggested that the depression causes the reduction of productivity, increasing health care cost and staff turnover of the organizations in the long run.

Also it was concluded that there is a gap in between the HR practices related to Work Life balance of employees in local and Foreign FMCG companies. This might have been one reason for the successful operation of foreign giant companies in Sri Lanka. Also in Foreign FMCG companies because of the right HR practices related to work life balance they migh have

In order to improve the work life balance; different strategies can be recommended for the companies. Apart from the strategies that are currently in practice by the organizations like arranging annual excursions, get to gather parties, sports fiestas and other entertaining events; the companies are also suggested to provide flexi hours of working for all the employees irrespective of the designation especially in the seasonal times. Also the employees can be allowed to work from home for at least couple of times per week which would release a huge amount of stress through which the company can have a healthier and happier staff. Also this initiative will reflect the level of trust between employer and employee; since the supervisors won't be micromanaging each and every of their employees over their shoulders. In addition to that less rigid lunch schedules can be arranged where there won't be a specific lunch break hours but simply emphasize the employees they should take a reasonable time period for their 
lunch break at any time of the day as they wish.

\section{References}

Adikaram, D. S. (2016). IMPACT OF WORK LIFE BALANCE ON EMPLOYEE JOB SATISFACTION IN PRIVATE SECTOR COMMERCIAL BANKS OF SRI LANKA. International Journal of Scientific Research and Innovative Technology, 3(11).

Chartered Institute of Personnel and Development. (2007). Trade Unions: a short history. Retrieved from Chartered Institute of Personnel and Development: http://www.cipd.co.uk/subjects/empreltns/tradunin/tradu nihist.htm?IsSrchRes=1

Crosbie , T., \& Moore, J. (2004). Work-life Balance and Working from Home. United Kingdom.

Dissanayaka, N., \& Ali, M. H. (2013). Impact of worklife balance on employees performance: An Empirical Study on Seven Apparel Organizations in Sri Lanka. 3rd International Symposium South Eastern University of Sri Lanka.

Frame, P., \& Hartdog, M. (2003). From rhetoric to reality. Into the swamp of ethical practice: Implementing work-life balance. Business Ethics, 12(4), 358-398. https://doi.org/10.1111/1467-8608.00337

Frone, M. R. (2003). Work-family balance. In J. C. Quick, \& L. E. Tetrick, Handbook of occupational health psychology (pp. 143-162). Washington, DC: American Psychological Association. https://doi.org/10.1037/10474-007

Greenhaus, J. H., Collins, K. M., \& Shaw, J. D. (2003). The relation between work-family balance and quality of life. Journal of Vocational Behavior. Journal of vocational Behaviour, 63(3), 510-531. https://doi.org/10.1016/S0001-8791(02)00042-8

Greenhaus, J., \& Allen, T. D. (2011). Work-Family Balance: A Review and Extension of the Literature. In Handbook of Occupational Health PsychologyEdition: 2ndPublisher: APAEditors: James Campbell Quick, Lois E. Tetrick (pp. 165-179). Washington, DC: American Psychological Association.

Haar, J. M. (2013). Testing a new measure of WLB: A study of parent and non-parent employees from New Zealand. International journal of Human Resource Management, 3305-3324. https://doi.org/10.1080/09585192.2013.775175

MANAGEMENT PRACTICES, WORK- LIFE BALANCE, AND PRODUCTIVITY: A REVIEW OF SOME RECENT EVIDENCE. (2006). OXFORD REVIEW OF ECONOMIC POLICY, 22(4). doi: https://www.jstor.org/stable/23606775

NDB Securities. (2017, September 8). FMCG sector Archives. Retrieved from Business News: https://www.lankabusinessnews.com/tag/fmcg-sector/

Pocock, B. (2005). Work-life 'balance' in Australia: limited progress, dim prospects. Journal of Human Resources, 198-209. 


\section{Macrothink}

International Journal of Human Resource Studies

ISSN 2162-3058 2019, Vol. 9, No. 1

World Health Organization. (2017). Depression fact sheet. Retrieved from Worl Health Organization: http://www.searo.who.int/srilanka/areas/depression_factsheet.pdf

\section{Copyright Disclaimer}

Copyright for this article is retained by the author(s), with first publication rights granted to the journal.

This is an open-access article distributed under the terms and conditions of the Creative Commons Attribution license (http://creativecommons.org/licenses/by/4.0/). 